\title{
US Pagans and Indigenous Americans: Land and Identity
}

\author{
Lisa A. McLoughlin
}

Independent Scholar, Northfield, MA 01360, USA; Lisa@hemlockhouse.net

Received: 2 January 2019; Accepted: 27 February 2019; Published: 1 March 2019

\begin{abstract}
In contrast to many European Pagan communities, ancestors and traditional cultural knowledge of Pagans in the United States of America (US Pagans) are rooted in places we no longer reside. Written from a US Pagan perspective, for an audience of Indigenous Americans, Pagans, and secondarily scholars of religion, this paper frames US Paganisms as bipartite with traditional and experiential knowledge; explores how being transplanted from ancestral homelands affects US Pagans' relationship to the land we are on, to the Indigenous people of that land, and any contribution these may make to the larger discussion of indigeneity; and works to dispel common myths about US Pagans by offering examples of practices that the author suggests may be respectful to Indigenous American communities, while inviting Indigenous American comments on this assessment.
\end{abstract}

Keywords: US Pagans; Indigenous Americans; identity; land; cultural appropriation; indigeneity

\section{Introduction}

Indigenous American scholar Vine Deloria Jr. (Deloria 2003, pp. 292-93) contends: “That a fundamental element of religion is an intimate relationship with the land on which the religion is practiced should be a major premise of future theological concern." Reading of Indigenous American and Pagan literatures ${ }^{1}$ indicates that both communities, beyond simply valuing their relationship with the land, consider it as part of their own identity. As for example, in this 1912 Indigenous American quote: "The soil you see is not ordinary soil-it is the dust of the blood, the flesh, and the bones of our ancestors. [...] You will have to dig down through the surface before you can find nature's earth, as the upper portion is Crow. The land as it is, is my blood and my dead; it is consecrated; and I do not want to give up any portion of it." (Curley, a Crow Indian chief, quoted in Seton and Seton 2005, p. 80; as quoted in Deloria 2003, p. 146). Similarly, Pagans express their interdependence of their own existence with Earth: "To worship something you have to be separate from it, but I don't feel a need to worship nature. Actually, it's stronger than that: I don't feel it would make sense, because I am nature." (Harris 2012, p. 150).

This paper focusses on issues of land and identity on what is now known as the North American continent. Pagans require a relationship to the land to complete our identity. As individuals and as Earth-based cultures we need to be able to bond with the land we are on in order to be complete psychologically, socially, and spiritually. But Pagans in the United States of America (US Pagans) are transplanted people whose cultural traditions are rooted in Europe, Africa, and elsewhere, and who currently live, uninvited, on the lands of other indigenous cultures. Our history with the North American continent is not the same as that of its indigenous inhabitants, nor is it congruent with that of our ancestors with their ancestral lands. This paper, based on eight years of ethnographic

1 For authority on Indigenous American beliefs, this paper relies on the published first-hand accounts of Indigenous Americans in quotation, sometimes along with a Pagan quote addressing the same point for balance and comparison. 
participant-observation in the Pagan community and five years working for north eastern Indigenous American Tribes in the area of Indigenous Ceremonial Stone Landscape protection ${ }^{2}$, explores the issues that arise as a result of US Pagans being transplanted onto the North American continent which is already populated by Indigenous Americans. How do multiple, distinct, Earth-based cultures-Indigenous, and transplanted Pagan-navigate their relationships to the land and to each other? By focussing on what I propose is a common denominator-our reliance on the land to complete our identity-I hope that US Pagans and Indigenous Americans can find a way to relate to one another and the land that avoids cultural appropriation, and fosters a greater mutual understanding of our cultures.

This paper first discusses US Pagan and Indigenous American religious cultures as diverse; goes on to detail two types of Pagan knowledge (traditional and experiential); describes three aspects of land relative to experiential knowledge; then explores how the relationships of Indigenous Americans and Pagans rely on the land in the religious and political realms (with examples); and finally discusses how the complexities of these relationships on the North American continent might contribute to the larger debate about legitimacy, authenticity, and indigeneity in a global context.

This paper is written primarily for an audience of Indigenous Americans and US Pagans, and secondarily for religious scholars. To avoid speaking for Indigenous Americans, I have refrained from extensive interpretation of what has been written by them about their cultures, preferring to directly quote Indigenous American authors. I hope that Indigenous Americans will engage with US Pagans around these issues, and look forward to conversations that include more Indigenous American voices.

\subsection{US Pagan ${ }^{3}$ and Indigenous American Diversities}

According to a 2014 national Religious Landscape Study by the Pew Charitable Trust, (pewforum. org, accessed 14 December 2018) there are an estimated 956,000 self-described followers of "other" world religions ${ }^{4}$ living in the United States; while Reece (2014a, p. 35) using 1990-2008 data estimates 682,000 self-described Pagans living in the US. Regardless of which number is more accurate, there are a significant number of Pagans in the US, and because we are a diverse population, that means there are many US Paganisms. In this paper the term "Pagan" means a broad range of cultural/religious practices which do not have a recognizable name to most of the world and which are Earth-based (Berger et al. 2003, p. 3). This definition, with its core being "Earth-based" is conservative. Any one definition applied to such a diversity of practices such as comprise Paganism as a whole, is necessarily universalizing and simplifying, so only the most relevant and least contentious identification factor is chosen to focus on here, one widely utilized by both Pagans and Pagan scholars. ${ }^{5}$

2 For reference, my experience working with and for the Indigenous American community is in the area of Ceremonial Stone Landscape protection. In the course of the past five years, as a researcher for four federally-recognized and two state-recognized Tribes in the north eastern part of the North American continent, I have come into contact with Indigenous American spirituality where it meets the land-in the form of the Indigenous Ceremonial Stone Landscape. Although this experience could, under other circumstances, be considered ethnographic participant-observation, I have worked for these communities long enough to know that Indigenous Americans neither want nor need yet another anthropologist speaking for them. Thus, I am emphatically not speaking as an authority on Indigenous American spirituality or for any Indigenous Tribe or group. I include mention of this work in order to clarify my position as an accomplice in the work of protecting the tangible expressions of intangible Indigenous American heritage.

3 US Pagans realize that the term "Pagan" has been used by Christians on this continent in hurtful and derogatory ways toward Indigenous American peoples. Outside the US the term "Pagan" is also problematic as Christian-derived (Rountree 2018, p. 8). Still, to many US Pagans, "Pagan" is a term it is important to reclaim. It is used here only to refer to Pagans, not to Indigenous Americans.

4 The Pew Religious Landscape Study breaks out the following "Non-Christian Faiths" (a rounded total of 5.9\%): Jewish $(1.9 \%)$, Muslim $(0.9 \%)$, Buddhist $(0.7 \%)$, Hindu $(0.7 \%)$, “Other Faiths" (comprised of Unitarians and other liberal faiths in the 'Other Faiths' tradition (1.0\%), New Age (0.4\%), and Native American Religions (<0.3\%)), leaving "Other World Religions" at $0.3 \%$, the number, along with the US Census Bureau estimate of the total 2014 US population at 318.6 million, I am using to calculate the number of Pagans in the US. Note that this number also excludes (percentages from the whole) Atheists $(3.1 \%)$, Agnostics (4.0\%), those identifying as "Nothing in particular" (15.8\%), and those who "don't know" (0.6\%).

5 See e.g., Rountree 2017, p. 4; York 2003, p. 65; Berger et al. 2003, p. 3; Clifton 2006, pp. 41-44. 
Paganisms can be divided into roughly three types (Corban-Arthen 2018): Indigenous Pagan communities that have survived in-situ in Europe; Reconstructionist Pagans, primarily seeking to connect with their cultural heritage as practiced indigenously in their geographic area of origin; and Neo-Pagans whose practices are more eclectic and urban. This paper focusses on Reconstructionist US Pagans whose cultural roots and/or bloodline descends from Europe, but who currently reside on an American continent. ${ }^{6}$

In opening a discussion between Pagans and Indigenous Americans, it is important to draw a distinction between US Pagans and "new age enthusiasts" who are of concern to Indigenous American communities due to a history of cultural appropriation (Jocks 2003, p. 492). Hess (1993, p. 4) defines new-age practice and discourse as a 1960s-derived counter-cultural social movement comprised of a conglomeration of disparate elements which include: science, Eastern philosophy, psychology of human potential, Native American religion, Goddess religion, mind/body integration, and "all things understood to be 'Natural'". These elements, when combined by people outside the specific communities of practice, are not a lineage but rather a more or less random string of appropriations. Stripped of their context they have a high potential for misinterpretation and misapplication, and their use is unlikely to be appreciated by members within each of these communities be they Native Americans, scientists, or Goddess-worshippers, all of whom struggle to maintain their own distinct identities. In contrast to this definition of new age enthusiasts, when discussing US Pagans I am referring to members of world religions (York 2003, p. vii; Hackett 2003, p. xv) who have their own traditions to reach back to and are not attempting to appropriate Indigenous American traditions. Clifton (2006, p. 53) observes that "the contemporary Pagan movement generally displayed an internal taboo against appropriating American Indian ceremonies or nomenclature," and while it would be disingenuous to say that there is no communication or sharing (willingly or otherwise) of traditions among US Pagans and Indigenous Americans, there is little self-described overlap between the US Pagan and new age communities (14\%) (Reece 2014a, p. 41).

Indigenous Americans are also very diverse with a variety of spiritual traditions. This paper refers to Traditional Indigenous Knowledge as written about by Indigenous American scholars and practitioners themselves, building on common and over-arching themes of an Earth-based respect for Nature and reverent participation in $\mathrm{ki}^{\prime} \mathrm{s}^{7}$ web. This is not to suggest that Indigenous Americans remain stuck in a historical interpretation of their traditional knowledge, just the oppositereligion, embedded in culture, evolves from a traditional core that like all culture adapts over time. Indigenous Americans can address the importance of the religious aspects of their culture as it was and is practiced, especially how these beliefs have changed over time. It is my intention to leave room for Indigenous Americans to speak for themselves in this matter.

For example I find this quote from an Indigenous American leader telling in that she is seeking to maintain relationships of connection: "I think we can help lead and understand with our values system ... proven through centuries. It's just my hope that future generations, including our own, will go back to that value system that we have of interdependence and interrelationships." (Fawn Sharp, Quinault president, interviewed by Grossman 2017, p. 204)

\subsection{Bipartite US Paganisms}

Paganisms can be understood as emergent traditions which rely on two sources of knowledge-traditional and experiential. While each Paganism hangs on its own traditional cultural

6 I share a distrust (Rountree 2017, p. 12) for the term "reconstructionist" as denying the living, evolving aspects of Pagan pathways; see later discussion of experiential knowledge. The focus on US Pagans with European traditional knowledge is because this is the group I am most familiar with and is not meant as a commentary on which pathways are representative of US Paganisms as a whole.

7 "Ki" is a nongendered replacement for "it" when speaking of the sentient world invented by Robin Wall Kimmerer. For a discussion of the importance of pronouns see Kimmerer (2013, pp. 48-59); for a more thorough explanation of "ki" see Kimmerer (2015) 
framework(s), they have in common the recognition of these two sources of truth and authority, used to greater or lesser degrees in the different pathways of Paganism, each of which has challenges that are perhaps uniquely expressed on the North American continent.

Traditional knowledge, the more easily recognizable of the two authorities within Pagan practice, and the one most commonly evoked to differentiate among the many multiple pathways that are here included under the Pagan umbrella, stems from existing sources outside the individual. These include (1) historic sources such as primary and secondary documents, and archaeological study of material culture; and (2) ongoing research such as the anthropological study of Paganisms, oral histories, and ethnography within surviving Indigenous Pagan communities. Because traditional knowledge is portable - in oral, material, or written form - it is less contentious in the quest for identity in the North American context. It is primarily important for Native Americans and others to know that US Pagans have these traditions of their own on which to draw because it means they have processes by which to relate to the land without cultural appropriation of Native Americans'.

Experiential knowledge is gained by an interaction between humans and the material and/or energetic worlds. There are traditions of experiential knowledge born of interaction with the land mentioned in the writings of both Indigenous Americans (first quote) and Pagans (second quote):

"People must always be ready to experience new revelations at new locations. If this possibility did not exist, all deities and spirits would be dead. Consequently, we always look forward to the revelation of new sacred places and ceremonies." (Deloria 2003, p. 281)

"My feeling of place is both internal and external [...] There are different ways of knowing about place-from the geological study of rock formations, to the manner in which we humans have lived in our environments, to the ways in which we tell stories and myths, and our internalized feelings of relationships about the land with which we are connected.

In a sense, we connect with topographical formations of the land within our own bodies." (Greenwood 2012, p. 60)

Adler (2006, p. 199), in her landmark study of US Pagans, links experiential knowledge with ritual, as a direct connection of humans with the spirit of the natural world, an attempt to reconnect to the "interconnectedness of everything in the universe." These ritual and magical practices can take many forms. Examples include extremely adept practices such as Shamanisms, where peoples' energetic bodies move through time and space to effect change in the material and energetic worlds. More accessible practices include altered mind states brought on by drumming, dancing, chanting, and meditation (with or without sleep and/or food and/or guiding). Many of the details of these practices are not readily shared outside their communities of practice, or are spoken of in specialized terminology that relies on deep cultural knowledge. For example, some Pagan traditions deny the material and energetic worlds can be separated, and so make no distinction between them, while others contend that one or the other world is far more important.

The link among these highly diverse practices is that as a direct interaction, experiential knowledge is emergent, ${ }^{8}$ a process, not a static doctrine. Glassie poetically sums up the concept of emergence as it relates to and grows from history, emphasizing that the dynamic movement of what is considered reality is what is true and constant: "Accept, to begin, that tradition is the creation of the future out of the past. A continuous process situated in the nothingness of the present, linking the vanished with the unknown [...] its character is not stasis but continuity ..." (Glassie 1995, pp. 295-96) This term "emergent" is especially well-suited to US Paganisms as we are a nation of cobbled together identities that morph over time.

On this continent US Pagans recognize and respect the indigeneity of Indigenous Americans, while our own and/or our ancestors' indigeneity in Europe is something many of us continue to

8 This insight about emergence and Paganism comes from Jenny Butler (2018, p. 199); and understandings of how cultures and their definition and study changes over time from Bronner (1998) and Glassie (1995). 
explore here in our new home. So, where does that leave non-Indigenous US Pagans relative to the land we are on? It is here, in the practice of experiential knowledge that US Paganisms become differentiated from Paganisms practiced in their countries of origin. The material world, and to whatever extent one believes, therefore the energetic world-is rooted in our surroundings, and those surroundings are at base, land. In the case of US Pagans, this land is not the land of our biological or cultural ancestors.

\section{Land}

What is "the land"? For Earth-based cultures, the land is central. Deloria, a prominent Indigenous American scholar writes how his culture deems the land as its own sentient, religious force: "Religion cannot be kept within the bounds of sermons and scriptures. It is a force in and of itself and it calls for the integration of lands and peoples in harmonious unity. The lands wait for those who can discern their rhythms." (2003, p. 296) Similarly, Pagans perceive of the land itself as revealing religious ritual: "I can feel every festival emerge from the trees and the land around me. The equinoxes and solstices are even more apparent as the whole countryside seems to take on the responsibility of showing and honouring the time of year. This is such a huge blessing, to be able to be part of it." (Fox 2012, pp. 130-31).

To a Pagan, an animist ${ }^{9}$ with an Earth-based religion, the land consists not just of its material self, but also its sentient self, and the ancestors and spirits that inhabit it. These three strands of existence are woven together to form a conglomerate identity whose aspects can be separately interacted with only at risk of miscommunication. I have assembled ${ }^{10}$ a paragraph definition that I believe reflects core Pagan beliefs about ourselves and land. This paragraph is offered with the caveat that no one person can speak for all US Pagans:

We are rooted within a web that connects us to all of the universe, physically and energetically. Humans do not have a special privilege to act in ways that disrupt the harmony and balance of this web, rather it is our joint responsibility to maintain our connections in respectful and generous ways that show our gratitude to the spiritual energy that resides among and within all of Nature, including us. The web and all natural beings are animate in a way that requires our respectful attention. Our actions toward Nature should always reflect our gratitude for its and our existence.

Beyond a unifying statement for Paganisms, I suggest that this statement expresses a core that is shared by Indigenous American and Pagan beliefs, whereby all is sacred, dynamically interconnected, and alive. Deloria (below) explains an Indigenous American perspective, while Orr sets out a Pagan viewpoint:

"[...] the earth is alive and everything related to it is also alive, and land consecrates human activities and makes them something more than we have power to produce." (Deloria 2003, p. 146)

"To the Pagan, perceiving the world as an intricately woven fabric of relationships, every creature held within its community of being, its natural ecosystem, its context of home, there is and can be no separation." (Orr 2012, p. 107)

The land as a braid of these three strands: its material self; its sentient/animate self; and the ancestors and spirit(s) that inhabit it, complicates the discussion of how people (as individuals and as cultures) can relate to it, and through it, to each other.

9 Animism is used in the "new" sense of Harvey (2006, p. xi) "Animists are people who recognize that the world is full of persons, only some of whom are human, and that life is always lived in relationship to others. [...] animism is more accurately understood as being concerned with learning how to be a good person in respectful relationships with other persons." Note that "person" is not intended anthropomorphically. For Pagan discussions along these lines see e.g., Adler (2006, pp. 22-35); Orr (2010, p. 193); or for a more academic discussion Bennett (2010).

10 Sources used in creating this paragraph include: Corban-Arthen's primary research among Indigenous European Pagan communities (Corban-Arthen 2017), Reece's quantitative research among US Pagans (Reece 2014a, 2014b), Berger et al.'s (2003) Voices from the Pagan Census (of Pagans in the US), Hopman and Bond's (2002) qualitative interviews in Being A Pagan, MacLellan and Cross's (2012) collection of Pagan essays on place in The Wanton Green, Adler's (2006) wide-reaching qualitative study in Drawing Down the Moon, and my reading of (other) Pagan literatures. 


\subsection{Connecting with this Land and ki's Indigenous People}

US Pagans recognize that what is now called the North American continent is the land of origin for Indigenous Americans, the land where their ancestors are buried, and land that they have cared for, maintained themselves as energetic and material partners with-co-created-for many thousands of years. If, as Pagan and perhaps also Indigenous American traditions indicate, the land consists of its material self, its sentient self, and its ancestors and spirits, how is the balance that has been so carefully co-created between the land and Indigenous Americans affected by US Pagans and our desire to bond with the land, to enter this web? How does the endeavour of Pagans seeking to form a deep relationship with the land, to co-create with Nature an existence in place, time, and spirit/energy, change when the ancestors/spirits of the land belong to an indigenous tradition not our own? And finally, what is—or should be-our relationship with the people whose ancestral land this is? These questions exists on at least two levels: the more public, political level created by historical facts, namely US Pagans being settlers on Indigenous Americans' land; and the more private, religion-as-practice level. These issues are intertwined, because as Jocks reminds us, "Traditional American Indian communities do not conceive of 'religious knowledge' apart from its complex relations with other domains, including economics and politics." (Jocks 2003, p. 491); and also, more fundamentally, because both Paganisms and Indigenous American traditional religions are what scholars (Hackett 2003, p. xv) label as "lived religions", ones in which every-day and religious practices cannot be separated. But before dealing with them holistically, let us attempt to untangle and work with aspects of the religious and political issues separately.

\subsection{Connecting on the Religious Level}

As animists Pagans must consider the authority of the land itself. The sentient land has the prerogative to decide if ki wishes to co-create with the transplanted US Pagan community-either on a case-by case or a cultural basis. US Pagans' relationship with the land must be negotiated with ki in all its aspects, first and foremost with ki's animate self. While on the face of it this seems to be a very personal, very private religious practice, this negotiation involves Indigenous Americans because they have co-created with the animate Earth for so long that their energy is not necessarily distinguishable from other energy within the web. Yet, in this particular Pagan viewpoint, it is still the Earth that answers the first question: how does the balance co-created between kiself and Indigenous Americans change when Pagans enter? It being nearly impossible to think like the Earth, any answer humans feel they have heard would need to be given serious time and consideration to see if it is a true answer and not a projection of wishes or assumptions. However, this type of communication is something at which people with Earth-centred religions excel, and it might not be impossible to hear an answer. And the answer may not necessarily be a rejection. For example, it may be that on the time scale of the Earth, ki has gone through so many adaptations and adoptions of individuals and cultures that accommodating yet one more seems insignificant; or it may be that the special relationship the Earth has developed with Indigenous Americans in a particular place is so strong as to be only slightly effected by others; or even, ki accepts US Pagans' energy as compatible, their intentions as beneficial. The Earth may have different answers for different people, or for the same person at different times and places; and the capabilities of individuals and cultures hearing ki's answer will vary as well.

Bonding with the next two aspects of the land are equally fraught with questions: most salient, as alluded to above, bonding with the ancestral spirits of the land is complicated because the ancestors are not ours. Without getting into the fine points of belief of how ancestral and land spirits may or may not differ, for the US Pagan population the question of if and how to contact them must be mitigated in some way by our relationship with Indigenous Americans (see next section). Yet, Spirit, in the sense of a larger sacredness that pervades the universe, is not necessarily equal to spirits which might be localized by place, or ancestral spirits who originate in a person or bloodline, so, this point has the potential to be very complicated, to rest on those fine points of religious interpretations, but ultimately will depend on our collective abilities to hear from the spirits themselves. 
The final strand, the material earth, is problematic too in that Indigenous Americans and US Pagans share a penchant for places of power, and overlapping definitions of such. For example I have heard first hand from Indigenous Americans that isolated pockets of US Pagans clash with them over use of promontories for ceremony in the New England area. On a larger scale, public lands, for example those with chambers with solstice alignments and beaches with clear sunrise views, can get crowded during astronomically significant times, sometimes with non-Indigenous people leading "field trips" to these sites for amateur archaeoastronomers and others ${ }^{11}$. This can create tensions among US Pagans, Indigenous Americans, researchers, and new age enthusiasts. In addition, the question of US Pagan stone structures on Indigenous American lands is contentious not just because they may disturb an energetic equilibrium created by Indigenous Americans, or destroy an existing arrangement of stones invisible to the non-Native eye, but also because they serve as material markers of trespass, of one culture marking the indigenous land of another. For example, there is a large population of spiritual outdoors-people in western Massachusetts, some of whom create Buddhist-like stone stacks along public mountain trials. I am not aware of a conversation between these builders and Indigenous Americans about these structures. Personally I do not think spiritual people would persist in doing this if they realized in what light their structures were seen by some Indigenous people, at least not without further discussion. And this is taking into account only inadvertent entanglements. It must be admitted that certain Pagans feel entitled to move stone and build structures on both public and private lands, and not all of them have asked permission from the Earth and/or from Indigenous Americans to do so.

As these examples show, even what may seem like the most prosaic of relationships with the land, what we do on its surface with its stones, is one that is fraught with cultural implications. It is an area where a great deal of cross-cultural education and discussion is needed, and these discussions should be grounded in an understanding of the history of Indigenous land loss on this continent, which will be discussed in the next section.

\subsection{Connecting on the Political Level}

While both Pagan and Indigenous American traditions give autonomy and authority to the Earth kiself, political justice requires that US Pagans, being non-indigenous, somehow attempt to receive permission or recognition from Indigenous Americans, entering a conversation with the people who have themselves so long co-created with this land. While on a religious level, I am not sure any cultures that respect the Earth, including Indigenous Americans', would want to deny others a relationship with Spirit even if they dwell in other than their ancestral lands, there may be political reasons to resist cooperation. For example, allowing that any other group may have a right (Spirit-given or otherwise) to commune with land held sacred by Indigenous Americans might be seen as harmful to the assertion of a special, Indigenous relationship with their ancestral territories that have been co-opted by the federal government e.g., in the application of the American Indian Religious Freedom Act, which (uniquely) guarantees Native Americans the right to access federal public lands and to sacred objects that might otherwise be prohibited in pursuit of the practice their religions. This conversation is greatly complicated by the diversity of Indigenous Americans who hold heterogeneous current beliefs, and who face a variety of significant political challenges, some of which threaten the very existence of their cultures.

In such a political arena power relations become paramount. It seems to me that their generations of co-creation with the land grants Indigenous Americans a certain authority over what humans do on this continent. This authority arises from two sources. Firstly, it stems from their advanced ability

11 The same is true of many sacred sites in the UK, e.g., Stonehenge, a sacred Pagan site, is open to the general public on the equinoxes and solstices, creating more of a free-for-all atmosphere than that of a religious rite (personal experience, autumnal equinox 2015). 
to read what the land expresses as ki's wish, having worked with ki for many millennia. The second is rooted in ethics, philosophy, and politics-the indigenous traditional goal to keep intact the web we collectively depend upon for life. For at least these two reasons, Indigenous Americans must be recognized as having authority over the land of this continent when it comes to representing that land to other human beings in the public, political sphere. For example, I think Indigenous Americans have "the right of first refusal" for irreversible activities such as fossil fuel extraction or nuclear waste creation/disposal. By directly interpreting the will of the sentient Earth, and by protecting the web of life on which we all depend, Indigenous Americans have been working hard to help non-Indigenous people do the right thing for the continuation of life on this continent and planet. But what about Pagans? Politically, do Indigenous Americans feel any different about sharing this continent with Pagans than with any other settlers?

Indigenous Americans of this continent, may also decide-case by case (individual by individual) or on a cultural level-if they wish to accept and work with US Pagans. On the one hand, Indigenous Americans have every reason to wish us gone. US Pagans are settlers, uninvited guests. Yet despite our settler status here, I would like to offer some reasons for Indigenous Americans to consider opening a conversation with US Pagans about working together based on possible commonalities. As Deloria (2006, p. xx) writes: “[...] I could see many connections between the practices and beliefs of our ancestors and some of the thoughts of contemporary non-Indian thinkers. Reading the non-Indian materials reassured me that there was wholeness in the manner in which our ancestors related to the world that transcended the popular beliefs of today and had a place in human understanding alongside other great spiritual and philosophical traditions."

Reasons Indigenous Americans might consider working with US Pagans ${ }^{12}$ :

- Paganism, like any religion, seeks to answer the big questions-why are we here; how should we live. Like traditional Indigenous American religions, Pagans do this in the context of a lived (Hackett 2003, p. xv) not dogma-based (Berger et al. 2003, pp. 3-5) religion that is embedded in daily cultural practice and not within formal institutions.

- Pagans approach the world humbly and with a reverence and process that while not exactly the same, seems in harmony with that of Indigenous Americans. Ours are Earth-based traditions, honed over millennia albeit in different parts of the world.

- Pagans recognize and pay respect to the power of ancestral and long-term bonds to the Earth.

- The Earth needs all the people ki can get who think carefully about how we co-create ourselves and the rest of Nature, who are willing to stand up and protect this web of being from those who would destroy it with mainstream profit-driven values.

- The future of the Earth depends on all people accessing Spirit and applying a spiritual ethos to their actions.

\subsection{Reconnecting: Land and People; Religion and Politics}

The relationships between Indigenous Americans and US Pagans are deeply entangled on the political and religious levels. Since our relationship with the land is central, and part of the identity of the land consists of ancestral ties (which includes burials, Indigenous Ceremonial Stone Landscape, and more intangible forms such as ancestral spirits), how US Pagans are received by the descendants of those ancestors will affect our religious practice as we seek to bond to land in all its aspects. Thus, awareness of our position with Indigenous Americans is key to our individual religious practice whether or not our larger political situation is affected.

12 Admittedly, this is a list of the best and most compatible of common US Pagan traits—it cannot universally apply to such a diverse community. 
While US Pagans hope that our presence here could be part of the healing and strengthening of the Natural web, several issues stand in the midst of the question of how that might happen in concert with Indigenous Americans.

First, we haven't, on the whole, asked permission to be here. The question is, who do US Pagans need permission from-Indigenous American land, Indigenous American people, or both? Does it feel like another way for the land to be stolen away from Indigenous Americans when others enter into a spiritual relationship with it, even one built on respect? Our different history with this land must be part of this discussion. We can start by acknowledging that the land we are on has been co-created, maintained, and in most cases is un-ceded from Indigenous Americans. Anyone without this cultural tie is a settler, and it seems only fair and respectful to officially ask for permission in the political, public realm, even while many if not most individual US Pagans and US Pagan communities continue to practice their religion which necessarily involves bonding with the land. Despite the fact that most US Pagans have nowhere else to go, and regardless of how we have come to be on this continent-whether we unwillingly immigrated hundreds of years ago as indentured servants, or came to this country willingly and/or more recently, this question is relevant because in the political sphere it builds a foundation of respect, and in the religious sphere it tells us where we are in relation to the land spirits. I hope to learn more about the intentions of Indigenous Americans toward US Pagans from themselves; at this point I am trying not to presume we might be seen as any different than other immigrants. Whom to ask, and how, is a question for Indigenous Americans to determine. As settlers not indigenous to this continent, Pagans may be unwelcome whatever our beliefs, but asking should be part of any meaningful dialog. As Chelsea Vowel (Métis) writes in "Beyond Territorial Acknowledgements" (https:/ /apihtawikosisan.com/2016/09/beyond-territorial-acknowledgments/, accessed 19 February 2019) territorial acknowledgement has its place: "If we think of territorial acknowledgments as sites of potential disruption, they can be transformative acts that to some extent undo Indigenous erasure. I believe this is true as long as these acknowledgments discomfit both those speaking and hearing the words. The fact of Indigenous presence should force non-Indigenous peoples to confront their own place on these lands."

Secondly, if US Pagans and Indigenous Americans agree to work alongside and/or in concert, the material ways to do this work needs to be discussed. Take, for example, the issue of sacred places on the land. Can sacred places be shared? If so, how? Would this be at the same time? At different times? And how would the use of one space by one group effect the use by another? What about the building of stone and other structures?

Starting from a place of mutual respect, there is hope that sacred spaces could be shared. For example, state-recognized Tribes in California have worked successfully with the Office of Historic Preservation in the Department of Parks and Recreation to arrange for their right to hold rituals on their sacred mountains that exclude the general public, working through multiple cross-cultural issues in the process. As US Pagans and Indigenous American communities come together around particular lands, we may learn to partner over time, to draw on each other's strengths, as the archaeology and Indigenous communities are just starting to $\mathrm{do}^{13}$. Settler communities, even academics, are learning to take a step back as Indigenous Americans agree to share with us their expertise in working with the land $^{14}$. It is hoped that this paper may help dispel some misconceptions about US Pagans, and invite Indigenous Americans into conversations with us.

13 See e.g., Bruchac et al. (2010); Silliman (2008); Cippola (2018).

14 See e.g., Grossman (2017). 


\section{Examples of Respectful US Pagan Practice}

I would like to offer two concrete examples of respectful ${ }^{15}$ ways that US Pagans have found to relate to the Earth on this continent: one a personal practice, and the other a more communal one. They have several things in common. Foremost, because they are grounded in both experiential knowledge, and European Pagan traditional knowledge, they avoid appropriation of Indigenous American cultural knowledge. This is what sets apart US Pagans from the new age enthusiasts that so plague Indigenous American consciousness (Jocks 2003, p. 492)—Pagans have roots that we can reach back to for our own cultural practices, and we have traditions of experiential ways of knowing that allow us to connect authentically to the Earth. This does not negate the contentious problem that this part of the Earth is not the land of our ancestors, and we must admit and keep that in our minds as an issue to be dealt with the land itself, with the people whose land this has long been, and within our own hearts. I hope this next section will alleviate some of the Indigenous American concerns about cultural appropriation, to see that modern US Pagans are trying to do right—by this land, and by them.

\subsection{Sylvia V. Linsteadt}

The first example of what I see as a respectful approach to the land is that of Sylvia V. Linsteadt, an author, animal-tracker, and student of ancient history, who divides her time between coastal California and the mountains of Crete. The following is excerpted with the author's permission from her 2013 essay “Turning our Fairy Tales Feral Again,"16 (resiliance.org accessed 6 February 2019) which outlines the early germination of this philosophy in her artistic practice:

"[...] What would happen if my tracking eyes, ravenous for pawprints, bits of fur, old bones, the contours of thick manzanita chaparral and all the trails it holds, collided with my myth and folktale-loving imagination? How would the stories I know fare in this place? I live in the Coast Range foothills of central-northern California: redwood canyons, northern coastal scrub of coyote brush and bramble, red alder riparian corridors, wild thrashing foamed Pacific strand. [...]

There are deep stories already sung right up from this land. In this region, the oldest ones are Coast Miwok, Pomo, and Ohlone. Throughout California stories were once told in over three hundred different dialects, each dialect corresponding to a specific region-a specific watershed, as we think of it now. [...] Imagine how rooted those stories were, even as they shared themes, characters, and plots across the state and across the continent.

I wish that the heritage of my immediate ancestors in this place was not predicated directly upon violence, slaughter and oppression of a people and a way of life that had been grounded here for at least 9000 years. A people who had words for every kind of fog, and grass, and twitch of the fault-zone. [...]

But the thing is, their stories, all of them that are left intact, are not mine to touch. I have no right. My people have done enough meddling, enough ruining, enough destroying, and it is not my right now, a white girl made up of almost every imaginable white European culture, in my longing for rootedness, in my longing to belong to the land into which I was born, to go adapting and adopting the sacred stories of a people who my direct ancestors very likely discriminated against, probably even killed.

15 The determination of these as respectful is in the author's opinion, and she invites the Indigenous American communities' comments.

16 This essay first came to my attention excerpted in Sharon Blackie 2016 If Women Rose Rooted (London: September Publishing); and it was first published online by Dark-mountain.net. 
This is a source of shame and anger and humiliation for me that runs very deep, like a vein. I don't really like to address it at all, as it makes me feel uncomfortable, like crying, like hitting a wall with my fist. Certainly those are stories to be learned, revered, respected; but not retold, not in my voice. That's too easy-taking stories from others about the land you live on without listening and learning its stories yourself. Those were stories gathered and earned over millennia. We need to work for our own wild myths, break ourselves open to let them in.

But I am here. This land is my home now too, whatever baggage that statement carries with it. I have a duty and a longing to learn it and to belong to it and to sing out its strange, wild magic songs. And I wonder if the stories that my ancestors brought with them in their blood and their bedtime-tellings - the Irish ones, the Russian ones, the English and German — can find a new wild home in these lands too. If there is some transmutation in order, some shape-shifting, as tale-types have been doing the world over since the beginning, getting passed on and changed as people migrate. There are Snow White tales from West Africa to Chile, from Albania to Iraq and France to Louisiana. And while, yes it's true, tales are born from specific landscapes, languages and cultural contexts, can they not be re-rooted? Reincorporated, re-patterned, returned to their wildness in a new place?

I'm wondering if I could walk with old stories over these landscapes, plant them here, see how the bobcats, the Douglas firs, the manzanitas and the kestrels, the red-legged frogs and brush rabbits, how they take to them. [...] Can we break open old stories like you break open an egg or a fruit, find the ember, the seed, the heart, and regrow it here, with respect and with reverence and with great curiosity, in the places where we live now?

I, for one, am going to take them out with me, [...] I'm going to carry them out of the books and into the wind. [...] How will you shapeshift with the redwood-coastal fog on your necks, the resin of chaparral on your tongues? What do your wild bodies look like and how will they run, set loose from the prints they've left on the page? [...]"

Linsteadt's blending of culturally-grounded stories (traditional knowledge from her own cultures) with experiential learning about the Earth in relation to those stories, a "seeding" of her cultural heritage into her adopted land, strikes me as a very respectful, honourable, and grounded practice that allows new roots to form while adding, rather than taking from the land. Putting the history out there and letting the land decide what roots and grows-asking the land directly for a foothold, without stealing from or leaning on the cultural heritage of those indigenous to the continent-Linsteadt's approach demonstrates an unusually acute consciousness of the complexities of being born and living on a continent that is not her biological or cultural ancestors'. Stories like hers help elucidate issues that all US Pagan should be wrestling with.

\subsection{Ardantane}

Example two is similar to the first in that it too avoids cultural appropriation by relying on traditional cultural knowledge from Europe, and on direct experiential knowledge based on European Pagan traditions. There are differences however. It is on a larger, community-wide rather than individual scale, and the people involved have not kept themselves separate from the Indigenous community of the area; they claim to have a good relationship with local Indigenous people, one built on mutual-respect and a certain amount of separation of practice (McShee 2018). ${ }^{17}$

17 The following has been vetted and approved by Ardantane, and much of the information comes from an article in The Wild Hunt by Sean McShee, as indicated, used with the publisher's permission. 
Ardantane is a 27 acre adult Pagan educational program and experiment in Pagan land management. Set on the edge of a national forest in New Mexico, the school's campus has been extant for 16 years and has served over 1000 students. They attempt to manage the land sustainably and with respect within their financial constraints, using state-of-the-art water treatment, controlling erosion, planting once-prevalent native grasses, and aspiring to solar energy and rainwater harvesting.

This US Pagan community is based in its own European Pagan cultural traditions. Their shrines are to European Pagan Goddesses (e.g., Brigid) and their modes of worship are from their European roots (e.g., labyrinths). They respect Indigenous American traditions and the work that Indigenous Americans currently do with their spirits, so rather than seeking out and attempting to appropriate these spirits, they "focus more on Celtic and European Indigenous spirituality." (Amber K as quoted McShee 2018). However, through experiential processes, sometimes spirits indigenous to this land will find them: "Ardantane does not seek out Native American spirits, but those spirits may still manifest themselves. Rowan [an Ardantane member] reported that 'Spider Woman came through pretty forcefully in one ritual to say we were "throwing a party in her house" and we hadn't invited her! Needless to say, she has since become one of our patron (matron, if you prefer) Goddesses.'" (as quoted in McShee 2018)

They are also careful to show respect to all the resident spirits who do not manifest: "Ardantane staff thanks the local land spirits regularly. They ask those spirits for their help in relating to the land. They also have a shrine to the Ancients both human and other." (McShee 2018)

This hybrid of European Pagan traditional practices and pantheons, plus a respectful and open attitude toward the indigenous spirits of the land that wish to manifest, is an example of another way US Pagans attempt to ask the land (in ki's material, energetic, and spirit-filled self) for permission to be here in a place where our ancestors and spirits were not born.

\section{Decoupling Issues of Indigeneity and Authenticity}

If, as the Indigenous American scholar Vine Deloria Jr. (Deloria 2003, p. 293) writes "What a religion does to a group of people on a distinct land is thus a vital question for future analysis.", the study of transplanted US Pagans could be of use to scholars interested in relationships between land and people globally, e.g., those studying Indigenous Pagans in Europe and elsewhere. The folklorist Bronner (1998, p. 5) asserts "What makes the United States so significant to contemplate is the special problem of joining tradition and modernity in a diverse, emergent social landscape to fashion a distinct cultural identity." Part of that identity involves issues of colonization (internal and external) and thus raises issues of indigeneity that are relevant beyond US borders.

Scholars of Paganism devote a great deal of attention to defining indigeneity. Questions of legitimacy and authenticity of religions and cultures old and new are conflated with questions of indigeneity, which are framed around authentically-rooted lineages. These lineages can be in one or more categories: cultural heritage, land/geography, and bloodlines (Rountree 2018, p. 4). Authenticity and legitimacy seem to rest on a proof of all three categories being valid, the measure of validity varying in its level of required specificity and length of time. Passing this test of authenticity means the particular practice could be considered "indigenous".

In Europe, indigeneity matters. As Bruchac (2010, p. 365) contends, the politicization of the term indigenous is "linked to efforts by the United Nations to honour and to highlight the human rights concerns of multiple world communities". Gregorius (2018, p. 64) confirms that in relation to European Pagans, "Claiming ancient roots is a common way of seeking legitimacy for religious practices". This is important to various European Pagan groups that are seeking to lay claim to their cultural heritage and through it, the land and/or political landscape of a country. For example Ivakhiv (2005) details how each aspect of lineage claims contributes to Ukrainian Pagans' sense of authentic identity to themselves and sometimes differently, to scholars.

Central to Ukrainian Pagans' self-identity as the first of the three strands, traditional cultural knowledge (2005, p. 220), is the Book of Veles which is largely considered a forgery by academics. 
Ivakhiv goes on $(2005$, p. 221) to explain the Native Faith movement in Ukraine as deeply influenced by the second strand, soil, in its form of geo-politics:

"The task of building a national identity appropriate to a modern state has been undertaken in a context that, to Ukrainians, has appeared to harbour multiple threats [...] It is understandable, in this context, that some Ukrainians would have turned to a kind of national mythmaking more characteristic of the Romantic nationalists of nineteenth- century Europe. Although nationalism has taken many forms, there are, in Ukraine, no obvious historical hinges on which to build an image of previous glory [...] Some have, therefore, looked beyond the historical record to the deep mists of prehistory."

Finally, Ivakhiv explains how bloodlines are also a factor (2005, p. 234) "[...] the ideology underpinning the Native Faith movement presumes a "natural" relationship between Ukrainians and the Ukrainian land that excludes the possibility of non-Ukrainians having a legitimate place in that land" Together, Ukrainian Pagans argue these categories give them authenticity and legitimacy that translates into authority over the material and geopolitical landscape. ${ }^{18}$

In the US we also argue over authenticity and legitimacy of Pagan practices, but here those arguments are not linked to land claims or treatment as indigenous from our government simply because we are not indigenous here-those battles belong to Indigenous Americans. In terms of traditional knowledge, whatever bits and pieces comprise our heritage here in the US we can still see (or seek) ourselves as part of a line of people stretching back to our countries of origin, practicing "the old ways" (Adler 2006, p. xiii). If you go back far enough all knowledge is emergent, and in the end, US Pagans have what we have, even if we know or suspect that for most of our many pathways, the majority of this traditional knowledge is not handed down unadulterated. This is not an unprecedented position for cultures that have experienced suppression and/or transplantation. Some Indigenous American Tribes find themselves in this predicament as well, being in a position of learning from anthropologists who study other cultures and historical texts, and searching for clues to their history since their elders no longer possess very much of this information. ${ }^{19}$ So US Pagans move beyond traditional knowledge into an emphasis of experiential knowledge. It may be this decoupling of authenticity of traditional knowledge and legitimacy on the one hand, and indigeneity on the other that opens the space for other kinds of Pagan practice to be recognized as essential, namely experiential knowledge.

Experiential knowledge is defined in this paper as being gained via a direct relationship between humans and the energetic/material web of Nature, and as emergent and therefore dynamic. Experiential knowledge is key to refuting what Johnson (2002, p. 311) discredits as a straw position for indigeneity as static: "Indigenous is a conflicted substantive category of religions, then, because it implies stability by playing the straw man for religions in change, when in fact the religions it classifies are also in transformation [...]" A religious tradition that relies on experiential knowledge may be

18 This example is also typical of the way academic researchers pit their interpretations of indigeneity against those who self-identify as indigenous. It is troubling to me in the North American context because it mirrors anthropological claims on this continent that seek to frame the identity of current Indigenous Americans as other than Indigenous- to a region, or to a continent. From my perspective, the academic side has tended to under-emphasize the possibility that oppressed cultures will hide certain aspects of their histories as well as sacred practices, either of which may otherwise be convincing of their "authenticity" to outside researchers, because these histories or practices are not ready to be shared with outsiders at all, or have been deemed unsuitable to share with a given outsider researcher. Without casting aspersions on this particular study, with which I am not familiar and which (importantly) deals with a more dominant than oppressed culture, we sometimes forget that academic researchers, too, have a stake in these arguments, e.g., when they wish to study remains such as the Ancient One (AKA Kennewick Man) rather than return them to Indigenous Nations as the law (Native American Graves Protection and Repatriation Act) requires; or when they would like to carry out archaeological digs without consulting with Indigenous Nations as is too often the case in the US and in Canada.

19 e.g., Adler (2006, pp. 379-83) reports this trend in the 20th century Native American newspaper Akwesasne Notes which rejected western mainstream culture but conceded the difficulty of reclaiming traditional ways that had been adulterated by it. 
both born of the land (indigenous), and portable, as Bruchac writes (2010, p. 365) "Expressions of Indigeneity-as personal experience, political identity, global movement-have long been rooted in intricate, lived connections with unique landscapes, flora and fauna, human and nonhuman entities. [...] It is also pertinent to note, when one reflects on the experiences of modern communities in diaspora, that Indigenous identity is frequently quite portable ..." The United Nations Educational, Scientific and Cultural Organization (UNESCO) in its definition of intangible heritage specifically asserts that adaptation over time and place does not negate value as heritage and even as indigenous, that heritage is "traditional, contemporary, and living at the same time" and "inclusive and adaptive." (https:/ / ich.unesco.org/en/what-is-intangible-heritage-00003 accessed 2 January 2019)

So if the situation of US Pagans on the North American continent could add in any way to this international debate about indigeneity, authenticity, and legitimacy, one contribution may be that these concepts do not rely on traditional knowledge alone. Decoupling authenticity of claims of indigeneity and traditional knowledge, and emphasizing the essential place in Earth-based religions of experiential knowledge shifts the debate more from lineage and provenance of blood, books, and soil, and more into an intangible culture framework. In this framework, the practice that Rountree notices and deems "creativity" (Rountree 2017, p. 6) which fills in the gaps of traditional knowledge's provenance becomes understood as experiential knowledge, an essential part of how doctrine-free Paganisms change over time. As is often reiterated in this debate ${ }^{20}$, expecting any culture to remain static and uninfluenced in this age is not realistic. It is up to theorists to value or devalue the changes and adaptations of indigenous culture according to the views of the people experiencing them, not according to some external hierarchy of more or less authentic and thus more or less acceptable as legitimate.

\section{Unanswered Questions}

This paper has attempted to outline issues US Pagans face as transplanted people in terms of our relationship to our traditional and experiential cultural knowledge, and to the land we are on and the people Indigenous to this land.

Emergence is a theme well-suited to the North American continent and any work we do here with the land and ki's Indigenous People. Specifically, it is my hope that we can be accomplices with the people Indigenous to our new home. While we understand that as settlers we may not be welcome, most of us have nowhere else to go. This is not Indigenous Americans' problem, so we should have no expectation that they will deign to see us in any light other than as settlers; however, I hope this paper suggests that as fellow followers of Earth-based traditions we have something to offer that is at least less objectionable than what most settlers bring as baggage, and possibly something that would allow us to work together. As Walt Bresette, founder of Anishinaabe Niijii, "a movement of Native and Non-Native people dedicated to protecting the earth for the future generations to come." (http:/ / www.protecttheearth.org/, accessed 25 December 2018) said, "Community, like love and water, knows no boundary."

In conclusion, US Pagans continue our practice on this continent. While the US Pagan community remains diverse, as the proffered examples illustrate, there is a growing recognition of the importance of asking the land and its Indigenous people for permission to be here in both religious and political terms. This happens through sincere attempts to understand and work within the political realities that our different histories on this land create. For example, US Pagans recognize Indigenous Americans as the traditional and present co-creators with this land. This starting point is meant to be one of respect for Indigenous Americans, a common understanding from which we might be in dialog about how we can respectfully coexist and co-create in places long sacred to them, in places inhabited by the spirits of their ancestors, and we hope by ours as well. I am optimistic the proffered examples demonstrate that

20 e.g., Rountree (2017, 2018); Johnson (2002); Bronner (1998). 
we seek ways to access and work with the energetic and material aspects of this land while respecting the traditions and spirits of Indigenous Americans.

As a non-Indigenous person I have purposely avoided attempting to analyse Indigenous American cultural traditions, instead quoting directly from Indigenous authors. Similarly, it's important to note that no one person can speak for the very diverse US Pagan community. From my limited experience and from the literature, I believe the core of our approaches to our place within the natural web overlap. I hope that Indigenous Americans will find it worthwhile to be in conversation together about our participation and mutual support in co-creation of this place, at this time. I am only one person in a diverse community. I encourage US Pagans who have not already done so to reach out to both the land and their nearest human Indigenous American counterpart to offer to be in conversation.

Funding: This research received no external funding.

Conflicts of Interest: The author declares no conflict of interest.

\section{References}

Adler, Margot. 2006. Drawing Down the Moon: Witches, Druids, Goddess-Worshippers and Other Pagans in America, 2nd ed. New York: Penguin Books.

Bennett, Jane. 2010. Vibrant Matter: A Political Ecology of Things. London: Duke University Press.

Berger, Helen A., Evan A. Leach, and Leigh S. Shaffer. 2003. Voices from the Pagan Census: A National Survey of Witches and Neo-Pagans in the United States. Columbia: University of South Carolina Press.

Blackie, Sharon. 2016. If Women Rose Rooted. London: September Publishing, pp. 357-61.

Bronner, Simon J. 1998. Following Tradition: Folklore in the Discourse of American Culture. Logan: Utah State University Press.

Bruchac, Margaret M. 2010. Imagining the Future of Indigenous Archaeologies. In Indigenous Archaeologies: A Reader on Decolonization. Edited by Margaret M. Bruchac, Siobhan M. Hart and H. Martin Wobst. Walnut Creek: Left Coast Press Inc., pp. 363-68.

Bruchac, Margaret, Siobhan Hart, and H. Martin Wobst, eds. 2010. Indigenous Archaeologies: A Reader on Decolonization. Walnut Creek: Left Coast Press Inc.

Butler, Jenny. 2018. Paganism in Ireland: Syncretic Processes, Identity and a Sense of Place. In Contemporary Pagan and Native Faith Movements in Europe: Colonialist and Nationalist Impulses. Edited by Kathryn Rountree. New York: Berghahn, pp. 196-215.

Cippola, Craig N. 2018. Earth flows and lively stone. What difference does 'Vibrant' matter make? Archaeological Dialogues 25: 49-70.

Clifton, Chas. 2006. Her Hidden Children: The Rise of Wicca and Paganism in America. Lanham: AltaMira Press.

Corban-Arthen, Andras. 2017. Lessons from Indigenous European Survivals. Paper presented at the Feast of Lights, Sturbridge, MA, USA, February 10-12.

Corban-Arthen, Andras. 2018. An Introduction to Paganism. Williamsburg: The EarthSpirit Community.

Deloria, Vine, Jr. 2003. God Is Red: A Native View of Religion, 30th Anniversary Edition. Golden: Fulcrum Publishing.

Deloria, Vine, Jr. 2006. The World We Used to Live. In Remembering the Powers of the Medicine Men. Golden: Fulcrum Publishing.

Fox, Woody. 2012. Devon, Faeries and me. In The Wanton Green: Contemporary Pagan Writings on Place. Edited by Gordon MacLellan and Susan Cross. Oxford: Mandrake of Oxford, pp. 125-32.

Glassie, Henry. 1995. Tradition. The Journal of American Folklore 108: 395-412. [CrossRef]

Greenwood, Susan. 2012. The dragon waters of place: A journey to the source. In The Wanton Green: Contemporary Pagan Writings on Place. Edited by Gordon MacLellan and Susan Cross. Oxford: Mandrake of Oxford, pp. 55-65.

Gregorius, Fredrik. 2018. Modern Heathenism in Sweden: A Case Study in the Creation of a Traditional Religion. In Contemporary Pagan and Native Faith Movements in Europe: Colonialist and Nationalist Impulses. Edited by Kathryn Rountree. New York: Berghahn.

Grossman, Zoltán. 2017. Unlikely Alliances: Native Nations and White Communities Join to Defend Rural Lands. Seattle: University of Washington Press. 
Hackett, David G. 2003. Introduction to the Second Edition. In Religion and American Culture, 2nd ed. Edited by David G. Hackett. New York: Routledge, pp. xv-xvi.

Harris, Adrian. 2012. A life in the woods: protest site paganism. In The Wanton Green: Contemporary Pagan Writings on Place. Edited by Gordon MacLellan and Susan Cross. Oxford: Mandrake of Oxford, pp. 146-58.

Harvey, Graham. 2006. Animism: Respecting the Living World. New York: Columbia UP.

Hess, David J. 1993. Science in the New Age. Madison: University of Wisconsin Press.

Hopman, Ellen Evert, and Lawrence Bond. 2002. Being a Pagan: Druids, Wiccans, and Witches Today. Rochester: Destiny Books.

Ivakhiv, Adrian. 2005. The Revival of Ukrainian Native Faith. In Modern Paganisms in World Cultures: Comparative Perspectives. Edited by Michael F. Strmiska. Santa Barbara: ABC-CLIO, Inc., pp. 209-39.

Jocks, Christopher R. 2003. Spirituality for Sale: Sacred Knowledge in the Consumer Age. In Religion and American Culture, 2nd ed. Edited by David G. Hackett. New York: Routledge, pp. 483-95.

Johnson, Paul Christopher. 2002. Migrating Bodies, Circulating Signs: Brazilian Candomblé, the Garifuna of the Caribbean, and the Category of Indigenous Religions. History of Religions 41: 301-27. [CrossRef]

Kimmerer, Robin Wall. 2013. Braiding Sweetgrass: Indigenous Wisdom, Scientific Knowledge, and the Teachings of Plants. Minneapolis: Milkweed Editions.

Kimmerer, Robin Wall. 2015. Nature Needs a New Pronoun: To Stop the Age of Extinction, Let's Start by Ditching 'It'. YES! Magazine. Available online: http:/ / www.yesmagazine.org/issues/together-with-earth/alternativegrammar-a-new-language-of-kinship (accessed on 28 February 2019).

MacLellan, Gordon, and Susan Cross. 2012. The Wanton Green: Contemporary Pagan Writings on Place. Oxford: Mandrake of Oxford.

McShee, Sean. 2018. Ardantane, a Pagan school and experiment in Pagan land management by in. The Wild Hunt, October 2. Available online: https:/ / wildhunt.org/2018/10/ardantane-a-pagan-school-and-experiment-inpagan-land-management.html (accessed on 6 December 2018).

Orr, Emma Restall. 2010. The Wakeful World: Animism, Mind and the Self in Nature. Winchester: Moon Books.

Orr, Emma Restall. 2012. Pagan Ecology: On our perception of nature, ancestry and home. In The Wanton Green: Contemporary Pagan Writings on Place. Edited by Gordon MacLellan and Susan Cross. Oxford: Mandrake of Oxford, pp. 95-107.

Reece, Gwendolyn. 2014a. Prevalence and Importance of Contemporary Pagan Practices. The Pomegranate 16: 35-54. [CrossRef]

Reece, Gwendolyn. 2014b. Impediments to Practice in Contemporary Paganism. The Pomegranate 16: 150-77. [CrossRef]

Rountree, Kathryn. 2017. Introduction 'We Are the Weavers, We Are the Web': Cosmopolitan Entanglements in Modern Paganism. In Cosmopolitanism, Nationalism, and Modern Paganism. Edited by Kathryn Rountree. New York: Palgrave Macmillan, pp. 1-20.

Rountree, Kathryn. 2018. Introduction: Context Is Everything: Plurality and Paradox in Contemporary European Paganisms. In Contemporary Pagan and Native Faith Movements in Europe: Colonialist and Nationalist Impulses. Edited by Kathryn Rountree. New York: Berghahn, pp. 1-23.

Seton, Ernest T., and Julia M. Seton, eds. 2005. The Gospel of the Redman, Commemorative Edition. Bloomington: World Wisdom Inc.

Silliman, Stephen W., ed. 2008. Collaborating at the Trowel's Edge: Teaching and Learning in Indigenous Archaeology. Tucson: University of Arizona Press.

York, Michael. 2003. Pagan Theology: Paganism as a World Religion. New York: New York University Press.

(C) 2019 by the author. Licensee MDPI, Basel, Switzerland. This article is an open access article distributed under the terms and conditions of the Creative Commons Attribution (CC BY) license (http:// creativecommons.org/licenses/by/4.0/). 